\title{
Biogass emission prognosis at the landfills
}

\author{
${ }^{1}$ T. K. Bicheldey; ${ }^{2 *} E$. N. Latushkina \\ ${ }^{1}$ Faculty of Biology, Peoples’ Friendship University of Russia, Moscow, Russian Federation \\ ${ }^{2}$ Faculty of the Environment, Peoples' Friendship University of Russia, Moscow, Russian Federation
}

Received 22 May 2010; $\quad$ revised 18 June 2010; accepted 28 July 2010; available online 1 September 2010

\begin{abstract}
The present study aims to estimate biogas potential of two Russian landfills situated in the republic of Tatarstan and in Moscow Region. Due to environmental, economic, social and energetic consideration of biogas for human being, utilization of such a by-product would be of high concern. To date, there are seven biogas utilization projects which have been developed and implemented at municipal solid waste landfills of Russia. The purpose of the research was to determine the biogas potential at the closed landfills. During the studies held in 2008; sampling, transportation, storage of biogas and landfill soil samples, laboratory investigations; physicochemical and analytical methods for measuring of proteins, carbohydrates and fats in the organic part of the soil and the analysis of empirical data by the methods of computer modeling and mathematical statistics were carried out. The obtained results of the research; concentrations of biogas components: methane, carbon dioxide, carbon oxide, nitrogen, hydrogen and oxygen, gas flows, composition of the organic part of the fields and analysis of gas distribution on the surface of the landfills; has shown scientific and practical importance. Results could be used for the assessment of biogas potential at the landfills for further biogas utilization projects implementation with electrical or thermal energy production.
\end{abstract}

Keywords: Air pollution; Atmosphere; Carbon dioxide; Methane; Solid waste

\section{INTRODUCTION}

Up today there is a positive correlation between the growing amounts of consumed products and the amounts of municipal solid waste generated by the population. Every year, about 400 million tons of solid wastes are accumulated in the biosphere. Such streams of matter are equal to the geological scale. The annual accumulation of such amounts of wastes arise a global environmental problem which requires urgent actions. Biogas is released into the atmosphere as a result of solid wastes' bio-destruction which consequently affects the natural environment, human health and causes the fires in the layers of the accumulated wastes in the landfills and dumps. Anaerobic digestion in the landfill sites is an environmentally friendly method of waste reduction and energy recovery (Bove and Lunghi, 2006; Banu et al., 2007; Tsai, 2007; Suthar and Singh, 2008; Babel et al., 2009; Øygard and Gjengedal, 2009; Monazzam and Park, 2009). Moreover, biogas can be considered as a renewable source of energy at the municipal landfill sites (Chou and Tsai, 2006; Suthar

\*Corresponding Author Email: elena_latushkina@mail.ru Tel./Fax: +8903 1422660 and Singh, 2008; Panjeshahi and Ataei, 2008). Attai et al. (1993); Berg et al. (2003); Bagchi (2004); Alexander et al. (2009) and Zaman (2010) investigated the advantages of biogas utilization methods. Egolfopoulos et al. (2001); Desideri et al. (2003); Gregersenb and Ravena (2007) and Huber-Humer et al. (2009) proposed the ways of landfill gas treatment at the landfill sites. The investigations of biochemical processes at the landfills were studied (Willumsen, 1990; Hassani et al., 2004; Krongthamchat and Riffat, 2005; Karapidakis et al., 2010; Pattnaik and Reddy, 2010; Zhang et al., 2010; Zulquer Nain and Jawed, 2010). Biogas utilization can provide huge amount of electric power (Shabani Kia and Taleghani, 2004). In addition, European countries handle this issue by adoption of national legislation and implementation of biogas utilization projects (Bradley et al., 2009). In spite of available methods and technologies for biogas utilization, these technologies are not still widely used in Russia where this is mainly frequent due to lack of the legislative requirements for biogas utilization and control. Solid waste landfills and dumps in the majority of the researches are 
considered as complex heterogenic systems, solidphase reactors of geological scales, systems of anthropogenic origin, the recourses with high content of organic substances, the renewable bio-recourses for the production of fuel. It is known that the amount and composition of biogas generated in the landfills and dumps depends on the following factors: morphological, fractional and chemical compound of wastes, the wet, the density, the acid value, the temperature, the height of accumulated waste, the isolation of the layers and microbiological conditions. According to Batrakova et al. (2005), the main components of the biogas at the landfills of Russia are methane (40-70\%) and carbon dioxide (30-60\%) which are the greenhouse gases. There is an opinion that the general and extensive utilization of biogas in all landfills and dumps will allow to obtain a variety of positive effects: from environmental point of view, by reducing the amounts of greenhouse gases emitted to the atmosphere from the landfills and dumps; from energetic point of view the biogas can be used as a fuel by the production of thermal energy or electricity; from economic point of view the biogas can be sold in the internal market of the country; from social point of view there will be new vacancies in the sphere of biotechnologies in the newly organized or "upgraded" landfills. The investigations which allow making a prognosis of the amount of biogas emissions from dumps and landfill sites are considered perspective and topical one. The main results of investigation of two Russian landfills are given below. The first landfill is situated near the city of Kazan, the capital of the republic of Tatarstan; the second one is situated near the city of Mytischi in Moscow Region.

The landfill in the Republic of Tatarstan was under operation since 1960s stretched in 29 ha. The landfill is divided into two parts. The storage of the solid waste in the first part was completed twenty years ago (1990), after that the second part of the landfill was opened. Its design capacity would have been achieved in 2009. However, nowadays the local government cannot take a decision to close the landfill because of the growing amounts of the solid waste generated by the population of the city of Kazan. The landfill in Mytischi Region was under operation since 1987; its area is 16.14 ha. The landfill was also divided into two parts. The first part achieved its design capacity in 2002 and after that was closed and recultivated. The second part has been operating since
2002. The closure year of this part is expected in 2012 . Field studies at the landfill of Kazan (the republic of Tatarstan) were carried out in spring 2008, at the landfill of Mytischi Region - in autumn 2008.

\section{MATERIALS AND METHODS}

The main purpose of the field studies was to determine biogas potential of two landfills. The sampling periods in two landfills took several days. They included sample collection $(10 \mathrm{~h})$, transportation of samples (12 h), laboratory investigations for measuring proteins, carbohydrates and fats in the organic part of the field samples (two days). Data handling took two weeks.

Both landfills are situated in the regions with temperate climate. The average annual temperatures are: in the city of Kazan $4.1^{\circ} \mathrm{C}$ and Mytischi Region $5.8^{\circ} \mathrm{C}$. The average annual humidity in the region of the first landfill (near the city of Kazan) is $75 \%$ and in the region of the second landfill (Mytischi Region) is $76 \%$.

The selected methods of the field gas-chemical researches were aimed to determine the current gas productivity of the landfills. The measurements of biogas components and field samples were carried out on square grids, the distances between the points were determined depending on the landfill's area and the surface of the fields. At the landfill near the city of Kazan there were 25 points: 11 points at the first (closed) part and 14 points at the second part of the landfill (which is under operation). The distance between the points was about $60 \mathrm{~m}$. At the second landfill in Mytischi Region, 65 points were chosen: 32 points at the first part and 33 points at the second part. The average distance between the points was $50 \mathrm{~m}$. The concentrations (grams per cubic meter) at the landfill near Mytischi Region and gas flows $\left(\mathrm{m}^{3} / \mathrm{m}^{2} / \mathrm{h}\right)$ at both landfills were measured by the gas analyzer (GA-94.A) from the depth of 0.6-0.8 m. Biogas samples at the landfill of Kazan were taken by samplecollecting devices with the volume of $200 \mathrm{~mL}$ from the depth of $1.5 \mathrm{~m}$ from each point. This method was aimed to analyze biogas content in the layers of waste. The obtained 25 samples were transported to the laboratory of the Academy of Communal Services (Moscow) where they were studied.

Specification and selection criteria of sampling were based on obtaining interpretive results. To study the organic compound of the landfill, 75 samples of the field by the amount of $100 \mathrm{~m}^{3}$ at the landfill of Kazan were 
taken. Three samples from each point at both parts of the landfills (from 25 points of the Kazan landfill and 65 points of the landfill in Mytischi Region) were taken. 195 field samples at the landfill were taken of Mytischi Region The laboratory studies were directed to determine the qualitative and quantitative composition of biogas and field samples according to standard methodologies of gas chromatography, chemical and analytical analysis. Gas chromatography allowed determining gas concentrations within the following limits: $0.01 \%$ methane, carbon dioxide and nitrogen, 0.0001 hydrogen sulfide, nitrogen oxide, ammonia, hydrogen and nonorganic combustible gases, $10^{-5} \%$ hydrocarbons and hydrocarbon compounds. The percentage error was equal to $5 \%$. The chromatograph "Chrom-5" was used to measure biogas composition. A sample of biogas was fed to the column of chromatograph with special adsorbent (molecular sieves to determine $\mathrm{CO}_{2}, \mathrm{CH}_{4}, \mathrm{~N}_{2}$ and $\mathrm{H}_{2}$ and polisorb-1 to determine $\mathrm{CO}_{2}$ ). Separation of gases in the columns was carried out at the temperature of $50^{\circ} \mathrm{C}$. After a fixed period, a detector registered the content of each gas component. The peaks of $\mathrm{CO}$ at the first detector were registered in $5 \mathrm{~min}$ and $15 \mathrm{~s}$, for $\mathrm{N}_{2}-$ in $2 \min 27 \mathrm{~s}$ and for $\mathrm{CH}_{4}-$ in $4 \mathrm{~min}$ and $12 \mathrm{~s}$. The peaks at the second detector of $\mathrm{CO}_{2}$ were registered in $7 \mathrm{~min}$ and $15 \mathrm{~s}$. The obtained chromatogram had the peak for each detected gas component. The composition of gases was found by the spaces of peaks. Gas chromatography determined the following gases in biogas at the landfill of Kazan: $\mathrm{CH}_{4}, \mathrm{CO}_{2}, \mathrm{CO}, \mathrm{N}_{2}$ and $\mathrm{H}_{2}$. The biogas at the landfill near Mytischi Region was consisted of $\mathrm{CH}_{4}$, $\mathrm{CO}_{2}$ and $\mathrm{O}_{2}$. The obtained empirical data were mathematically and statistically processed according to Latushkina (2003). The methods of statistics included cluster and factor analyses, determination of correlations between gas components and the organic compound of waste.

The conducted studies allowed to characterize the processes of gas generation and to provide the gasgeochemical zoning of the landfills. In addition, the modeling of gas emission processes on the subsurface layer of the fields has been carried out. The method of data interpolation included the construction of the contour maps of gas concentrations.

\section{RESULTS AND DISCUSSION}

The main results characterizing the processes of gas generation in the studied landfills are as follows:
First, the intensity of methane generation does not depend on the location of sampling points, i.e. the methane generates constantly both in central parts and in the periphery of the landfill - at the slopes of the accumulated wastes. The damage of water-proof membranes also facilitates the methane emission to the atmosphere.

Second, the intensity of gas generation does not depend on the height of the accumulated solid wastes. The correlation analysis of gas concentration in the samples and the heights of the wastes' layer confirmed this thesis. Average concentrations of $\mathrm{CH}_{4}$ in the first (closed) parts of the landfills account $432.8 \mathrm{~g} / \mathrm{m}^{3}$ and $129.5 \mathrm{~g} / \mathrm{m}^{3}$, the concentrations in the second (operated) parts are 395.7 and $334.9 \mathrm{~g} / \mathrm{m}^{3}$. The concentrations of $\mathrm{CO}_{2}$ in biogas in the closed parts are equal to 664.3 and $280.0 \mathrm{~g} / \mathrm{m}^{3}$, the concentrations of carbon dioxide in the operated parts are 751.7 and $725.7 \mathrm{~g} / \mathrm{m}^{3}$. The height in the landfill of Tatarstan varies within 189 and $201 \mathrm{~m}$ above sea level. The height of accumulated waste at the landfill near Mytischi Region varies within 149 and $172 \mathrm{~m}$ above sea level. The correlation coefficients of gas concentrations and heights of the points from which gas samples were collected are less than 0.40 . Third, the physical, chemical and biochemical processes in the studied landfills are different. This thesis is based on the study of morphological and chemical content of the accumulated wastes and also climatic conditions of the regions where the landfills are located. It was confirmed by the comparison of the correlation coefficients between the values characterizing the content of methane and carbon dioxide in the samples. The parameters of the field of gas concentrations vary within -0.95 units for the first part of the landfill and 0.94 units for the second part at the landfill of Tatarstan. The values of correlation coefficients at the landfill of Mytischi Region are 0.79 for the first part and 0.84 for the second one.

The concentrations of organic compound in the closed parts of the landfills are $71.4 \%$ (Tatarstan) and $72.7 \%$ (Mytischi Region) which means that $71.4 \%$ in the first landfill and $72.7 \%$ of waste in the second landfill can be degraded with biogas emission. The correlations coefficients of gas concentrations and the organic compound of wastes are less than 0.14 .

On the basis of the obtained empirical data 3-dimension models of the sites with contour maps of landfill gas 
concentrations distributed along the surfaces of the objects were arranged (Fig. 1). The modeling of gas emission process was made by the method of interpolation realized by the program pack Surfer version 9.8-2009. To trace isolines of gas concentrations the obtained data were adapted by geo-statistical method of data interpolation called Krigging realized by the Surfer distributing gas concentrations by long irregular distances between the separate points and to obtaining the grid with regular distributed values. The method of data interpolation showed the irregular accumulation of gases on the subsurface layers of the studied landfills: the accumulation of gases was registered both at central and peripheral parts of the landfills. The estimation of gas potential of the landfills was carried out according to the approved Russian methodology, developed by the scientific group headed by the specialists of the Academy ofCommunal Services of Russia by Abramov et al. (2004). It is necessary to point out that the gas potential was accounted for the second parts of the landfills (operating parts) as the most perspective for the realization of gas collection and utilization projects. The total emissions of biogas $\left(G_{\text {total }}\right)$ were accounted according to the Eq. 1.

$G_{\text {total }}=M_{\text {total }}\left[\frac{a \cdot 365 \cdot 24 \cdot 3600}{12}+\frac{b \cdot 365 \cdot 24 \cdot 3600}{12 \cdot 1.3}\right] 10^{-6}$,

Where,

$M_{\text {total }}$-a peak of emission of biogas per second, grams per second;

$a$ - warm period of the year (months) with the temperature higher than $8{ }^{\circ} \mathrm{C}$; $b$ - cold period of the year (months) with the temperature within $0-8{ }^{\circ} \mathrm{C}$;

1.3 - a rising coefficient of inequality which considers the irregular biogas generation when sampling the gases during the cold period of the year;

$365,24,3600$ - the coefficients, converting the seconds to the year.

The period of active biogas emission $(t)$ was accounted according to the Eq. 2 .

$t=\frac{10248}{T_{\text {warm }} \cdot\left(t_{\text {av.warm }}\right)^{0.301966}}$,

Where;

10248 И0,301966 - specific coefficients considering biochemical degradation of the organic compound of waste;

$T_{\text {warm }}$ - warm period of the year in the studied areas (days);

$t_{\text {avwarm }}$ - average temperature in the studied areas in warm period of the year, $\left({ }^{\circ} \mathrm{C}\right)$.

The conducted calculations allowed to state that the period of active biogas emission at the landfill in Tatarstan will be $22 \mathrm{y}$. In this case, the peak of biogas emission prognoses in 2009 and the amount of biogas emission will be 181250 tons/y; the average amount of biogas emission will be 19145 tons/y. The period of active biogas emission at the landfill in the Mytischi Region accounts $14 \mathrm{y}$, the peak of biogas emission will be 75620 tons/y (by 2011). On the basis of these data the comparative figures illustrating the processes of biogas emission decays at the studied landfills have

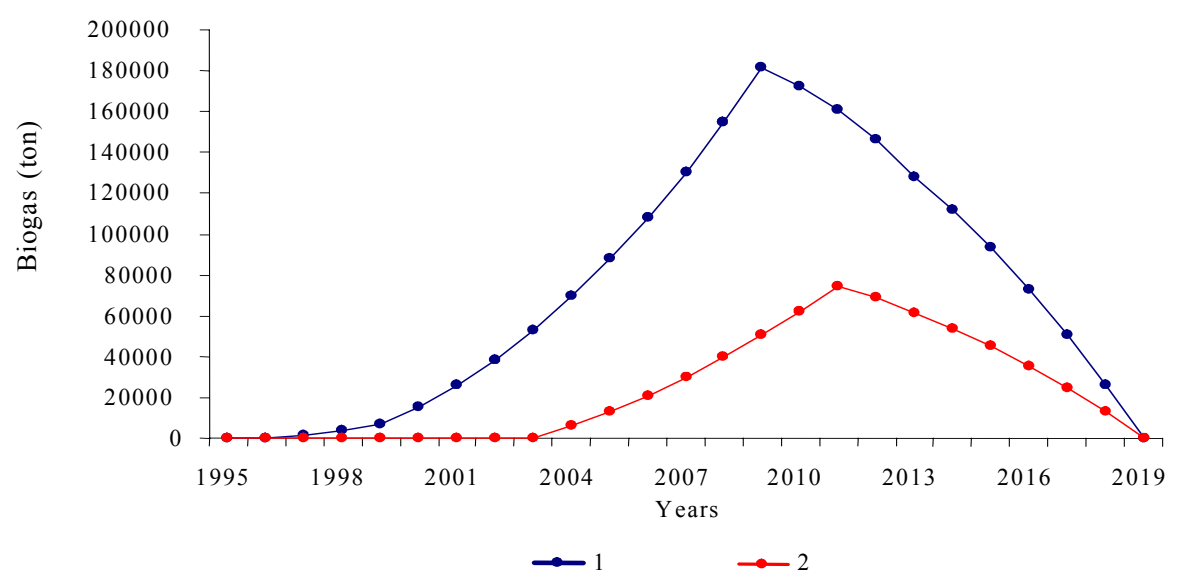

Fig. 1: Estimation of biogas emission at the municipal landfill sites: 1 - the landfill located in Tatarstan, 2 - the landfill located in Mytischi Region 
been set up (Fig. 1). According to the investigations of Chendler et al., (1983), Trosenko (1983); Lebedev et al., (1993), landfills in Russia can be the source of thermal or electrical energy. As demonstrated by Gurvich and Lifshits (2007), $1 \mathrm{~m}^{3}$ of biogas gives up to $1.3 \mathrm{kWh}$ of energy in Russian conditions.

In this way, at the landfill of Tatarstan up to 19900 megawatts of energy per year and at the landfill in Mytischi region up to $14600 \mathrm{Mw}$ of energy per year could be produced from biogas. Summarizing the research results, the landfills of Russia have a great potential from bio-energetic point of view. Moreover, the municipal solid waste landfills can be considered as a renewable source of energy.

Development of such type of projects could significantly reduce the negative effect to the atmosphere from greenhouse gases. Russia started to take over a successful experience from international countries in the field of biogas utilization projects from 1990s. The authors consider that the results of the investigations of two landfills will introduce new technologies and practices to the Russian Federation in the environmental sphere which can be replicated at other landfill sites throughout the country.

\section{ACKNOWLEDGEMENTS}

Financial support of the investigations were provided by LLC “C6 Capital”, Moscow (N PBO-23/08 02.02.08 and N P-05-08 07.06.08) under the framework of the project design documentation developed for Kazan and Mytischi landfills. The authors are grateful to Dr. Makarova of the Department of Geo-ecology and Berezkin and Burnakova of the environmental chair of Peoples' Friendship University of Russia for cooperation throughout the present study.

\section{REFERENCES}

Abramov, N. F.; Rusakov, N.V.; Sannikov, E.S., (2004). Quantitative Estimation of Atmospheric Emissions from the Municipal Solid Waste Sites, Academy of the Communal Services Named After Pamfilov, 14-29.

Alexander, C.; Curran, A.; Smaje, C.; Williams, I., (2009). Evaluation of bulky waste ane reuses schemes in England. Waste and Res. Manage., 162 (3), 141-150 (10 pages).

Attai, A.; Camacho, P.; Hesn, D.; Manem, G.; Marticorena, A.; Salmon, P., (1993). Prediñtion rules for biogas valorisation in municipal solid waste landfills. Sci. Tech., 27, 235-241 (7 pages)

Babel, S.; Pecharaply, A.; Sae-Tang, J., (2009). Anaerobic codigestion of sewage and brewery sludge for biogas production and land application. Int. J. Environ. Sci. Tech., 6 (1), 131-140 (10 pages).
Bagchi, A., (2004). Design of landfills and integrated solid waste management. Amazon, 15-22.

Banu, J. R.; Kaliappan, S.; Yeom, I. T., (2007). Treatment of domestic wastewater using upflow anaerobic sludge blanket reactor. Int. J. Environ. Sci. Tech., 4 (3), 363-370 (8 pages).

Batrakova, G. M.; Boyarshinov, M. G.; Goremykin V. D., (2005). Modeling of transference and discharge of methane in the atmosphere emitting from the municipal solid waste landfills. Herald of Voronezh Univ., 1, 256-262 (7 pages).

Berg, P. E. O.; Clarkson, P.; Mattson, C., (2003). The development of systems for property close collection of recyclables: Experiences from Sweden and England. Resour. Conserv. Recycl., 38 (1), 39-57 (19 pages).

Bove, R.; Lunghi. P., (2006). Electric power generation from landfill gas using traditional and innovative technologies. Energ. Convers. Manage., 47 (11-12), 1391-1401 (11 pages).

Bradely, P.; Druckman, A; Jackson, T.; Thomas, C., (2009). Accountong for food waste: comparative analysis within the UK. Waste and Res. Manage., 162 (1), 5-13 (9 pages).

Chandler R.E.; Lowry R.K.; McMeekin T.A.; Ratkowsky, D.A.; Stokes A.N.;, (1983). Model for bacterial culture growth rate throughout the entire biokinetic temperature range. Bacteriol., 154 (3), 1222-1226 (5 pages).

Chou, Y. H.; Tsai, W. T., (2006). An overview of renewable energy utilization from municipal solid waste (MSW) incineration in Taiwan. Renew. Sust. Energ. Rev., 10 (5), 491-502 (12 pages).

Desideri. U.; Di Maria, F.; Leonardi, D.; Proietti S., (2003). Sanitary Landfill Energetic Potential Analysis: A real case study. Energ. Convers. Manage., 44 (12), 1969-1981 (13 pages).

Egolfopoulos, F.N.; Qin, W.; Tsotsis, T.T., (2001). Fundomental and environmental aspects of landfill gas utilization for power generation. Chem. Eng. J., 82 (1-3), 157-172 (16 pages).

Gregersenb, K.H.; Ravena, R.P.J.M., (2007). Biogas plants in Denmark: Successes and setbacks. Renew. Sust. Energ. Rev., 11 (1), 116-132 (17 pages).

Gurvich, V.I.; Lifshits, A.B., (2007). The Experience and Perspectives of Landfill Gas Utilization in the Russian Federation. In International Seminar Commercial Use of Landfill Gas. Moscow, Russian Federation.

Hassani, A.H.; Moshirvaziri, S.; Torabian, A., (2004). Physicochemical and biological treatability studies of urban solid waste leachate. Int. J. Environ. Sci. Tech., 1 (2), 111 116 (6 pages).

Huber-Humer, M.; Lechner, P.; Mostbauer, P., (2009). Carbon Waste: Strategies for Treatment and Landfilling. Waste Res., Manage., 162 (4), 197-205 (9 pages).

Karapidakis, E. S.; Katsigiannis, Y. A.; Soupios, P. M.; Tsave, A. A., (2010). Energy efficiency and environmental impact of biogas utilization in landfills. Int. J. Environ. Sci. Tech., 7 (3), 599-608 (10 pages).

Krongthamchat, K.; Riffat, R., (2005). Specific methanogenic activity of halophilic and mixed cultures in saline wastewater. Int. J. Environ. Sci. Tech., 2 (4), 291-300 (10 pages).

Latushkina, E. N., (2003). Cluster analysis as the method of geoecological researches, Scientific Works of MPGU, 451454. 
Lebedev, V. S.; Lifshits, A. B.; Nekrasova, V. K.; Nozhevnikova, A. N., (1993). Microbiological processes in landfills. Water Sci. Tech., 27, 243-252 (10 pages).

Monazzam, M. R.; Park, B., (2009). Prediction of MSW Longterm Settlement Induced by Mechanical and DecompositionBased Compressions. Int. J. Environ. Res., 3 (3), 335-348 (14 pages).

Øygard, J. K.; Gjengedal, E., (2009). Uranium in Municipal Solid Waste Landfill Leachate. Int. J. Environ. Res. 3 (1), 61-68 (8 pages).

Panjeshahi, M. H.; A. Ataei (2008). Application of an environmentally optimum cooling water system design to water and energy conservation. Int. J. Environ. Sci. Tech., 5 (2), 251-262 (12 pages)

Pattnaik, S.; Reddy, M. V., (2010). Assessment of municipal solid waste management in Puduscherry (Pondicherry), India. Resour. Conserv. Recycl., 54 (8), 512-520 (9 pages).

Shabani Kia, A.; Taleghani, G., (2004). Tecnhical-economical analysis of the saveh viogas power plant. Renew. Energ., 30 (3), 441-446 (6 pages).

Suthar, S.; Singh, S., (2008). Vermicomposting of domestic waste by using two epigeic earthworms (perionyx excavatus and perionyx sansibaricus). Int. J. Environ. Sci. Tech., 5 (1), 99-106 (8 pages).

Trotsenko, Yu.A. (1983). Metabolic features of methane- and methanol-utilizing bacteria. Acta Biotech., 3 (3), 269-277 (9 pages).

Tsai, W. T., (2007). Bioenergy from landfill gas (LFG) in Taiwan. Renew. Sust. Energ. Rev., 11 (2), 331-344 (14 pages).

Willumsen, H., (1990). Landfill gas. Res. Conserv. Recycl., 4 (1-2), 121-133 (13 pages)

Zaman, A. U., (2010). Comparative study of municipal solid waste treatment technologies using life cycle assessment method. Int. J. Environ. Sci. Tech., 7 (2), 225-234 (10 pages).

Zhang, B.; Dixon, N.; El-Hamalawi, A., (2010). Development and evaluation of a phase relationship for MSW. Waste and Res. Manage., 163 (2), 67-75 (9 pages).

Zulquer Nain, M.; Jawed, M. (2010). Impact of sudden change in feed substrate types on steady response of suspended growth anaerobic reactors. Int. J. Environ. Res. 4 (2), 247 254 (8 pages).

\author{
AUTHOR (S) BIOSKETCHES \\ Bicheldey T. K., M.Sc., Ph.D., Research Student, The environmental faculty of Peoples' Friendship University of Russia, Moscow, Russian \\ Federation. Email: tayraa@list.ru \\ Latushkina E. N., Ph.D., Lecturer, The Environmental Faculty, Peoples' Friendship University of Russia, Moscow, Russian Federation. \\ Email: elena_latushkina@mail.ru
}

How to cite this article: (Harvard style)

Bicheldey T. K.; Latushkina E. N., (2010). Biogass emission prognosis at the landfills. Int. J. Environ. Sci. Tech., 7 (4), $623-628$. 